\title{
PERKUATAN DAN STABILISASI BADAN JALAN MENGGUNAKAN SISTEM PLAT SPUN PILE
}

\author{
Putera Agung Maha Agung ${ }^{1}$; Dea Putri Tsabita ${ }^{2}$ \\ 1,2Jurusan Teknik Sipil, Politeknik Negeri Jakarta, \\ Jalan Prof.Dr.G.A.Siwabessy, Kampus UI-Depok (16424) \\ e-mail :putera.agungmagung@sipil.pnj.ac.id
}

\begin{abstract}
Some damages of the Jalan Lintas Selatan Road, Suradita-Kranggan has occured every year with the identical failure cycle. One of the effort to make problem solving is to replace the base of road body construction with a concrete plate construction supported by circular pre-stressed concrete pile foundation (spun pile) system. The system will carry on the upper structure or embankment (subgrade) since the below of the structure exists soft soil layers and the depth of hard layer soil reachs more than $10 \mathrm{~m}$. Later on, all vertical and horizontal forces including moments caused by the external loads can be retained by the plate and spun pile foundation system. The purpose of the study is to calculate the bearing capacity, negative friction force, settlement of spun pile group with using field test data (SPT and CPT); and diameter variation of pile is $30 \mathrm{~cm}$ to $50 \mathrm{~cm}$. From calculations with the average length of $1400 \mathrm{~cm}$ and diameter of $50 \mathrm{~cm}$ can be determined bearing capacity of 298.9 tons by SPT and 504.3 tons by CPT data, respectively. Then, lateral bearing capacity is 168.5 tons (free pile head) and 344.2 tons (fixed pile head). The settlement occurred of a single pile foundation is $9.40 \mathrm{~cm}$. The results of negative friction resistance were obtained is 81.9 tons. The group piles is designed of 2 (two) rows and 3 (three) columns and can be safe for receiving the construction and traffic loads. Based on the analysis results, the concrete plate and spun pile system has fullfilled to design criteria.
\end{abstract}

Keywords: spun pile, bearing capacity, negative friction, settlement, pile group.

\begin{abstract}
ABSTRAK
Kerusakan pada Jalan Lintas Selatan, Suradita-Kranggan terjadi setiap tahun dengan siklus kegagalan yang sama. Salah satu upaya penyelesaian masalah tersebut adalah mengganti landasan konstruksi badan jalan dengan plat beton yang didukung oleh sistem pondasi tiang pancang bulat beton prategang (spun pile). Sistem ini akan memikul struktur atas atau timbunan (subgrade) karena di bawah struktur terdapat lapisan tanah lunak dan kedalaman tanah keras mencapai lebih dari 10 m. Nantinya, semua beban vertikal, horizontal berikut momen akibat beban luar dapat ditahan oleh sistem plat dan pondasi spun pile. Tujuan studi ini adalah untuk menghitung daya dukung, gaya gesek negatif, dan penurunan dari kelompok tiang menggunakan data hasil uji lapangan (SPT dan CPT), dan variasi diameter tiang adalah sebesar $30 \mathrm{~cm}$ sampai $50 \mathrm{~cm}$. Dari hasil perhitungan dengan panjang rata-rata $1400 \mathrm{~cm}$ dan diameter tiang $50 \mathrm{~cm}$ dapat ditentukan daya dukung sebesar 298,86 ton (data SPT) dan 504,3 ton (CPT data) secara berurutan. Kemudian, daya dukung lateral sebesar 168,5 ton (kepala tiang bebas) dan sebesar 344,2 ton (kepala tiang terjepit). Penurunan tunggal ratarata yang terjadi adalah sebesar $9,40 \mathrm{~cm}$. Hasil tahanan gesek negatif diperoleh sebesar 81,9 ton. Kelompok tiang yang direncanakan adalah terdiri 2 baris tiang dan 3 kolom tiang dan aman untuk menerima beban konstruksi dan beban lalu lintas. Berdasarkan hasil analisis, sistem plat dengan spun pile telah memenuhi kriteria desain.
\end{abstract}

Kata kunci: spun pile, daya dukung, gaya gesek negatif, penurunan, grup tiang. 


\section{PENDAHULUAN}

Jalan Lingkar Selatan terletak di kecamatan Cisauk, kabupaten Tangerang merupakan jalan alternatif sepanjang $30 \mathrm{~km}$ yang menghubungkan Kotamadya Tangerang Selatan dengan kabupaten Tangerang (Gambar 1 dan 2). (Peta geologi, Turkandi et al, 1992). Pada tahun 2016 terjadi kerusakan yang menyebabkan amblasnya badan jalan sepanjang 377 meter, diperlihatkan dalam Gambar 3. Kerusakan jalan terjadi di dua lokasi, yaitu STA 0+159 sampai STA 0+224 sepanjang 120 meter, dan STA 0+350 sampai STA 0+607 sepanjang 257 meter. Setelah mengalami perbaikan pada tahun yang sama, jalan mengalami kerusakan kembali pada tahun 2017. Berdasarkan kondisi tersebut, dapat dilihat bahwa upaya perbaikan yang telah dilakukan sebelumnya tidak memberikan pengaruh yang signifikan, sehingga dibutuhkan upaya lain untuk meperbaiki jalan tersebut Salah satu upaya yang dapat dilakukan adalah dengan mengganti konstruksi jalan tersebut menjadi konstruksi plat beton dengan tiang pancang bulat beton prategang (spun pile) (Clisby et al, 1978).

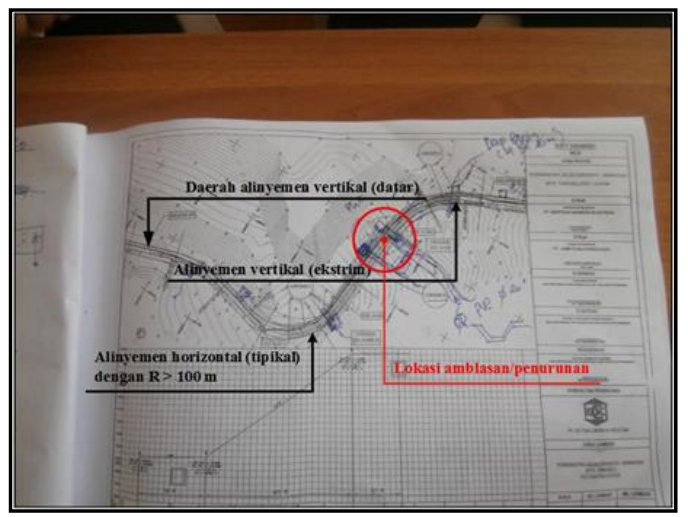

Gambar 1. Amblasan badan jalan Suradita -

Kranggan, Kabupaten Tangerang

Tujuan studi desain kombinasi plat beton dan spun pile ini adalah:

1. Menghitung nilai daya dukung tiang pancang dari data penyelidikan tanah SPT dan CPT.
2. Menghitung penurunan fondasi tiang.

3. Menghitung tahanan lateral tiang.

4. Menghitung daya gesek negatif.

5. Mendesain pola susunan tiang grup.

6. Menghitung jumlah tiang grup.

7. Menghitung daya dukung grup.

8. Analisis stabilitas aksial tiang

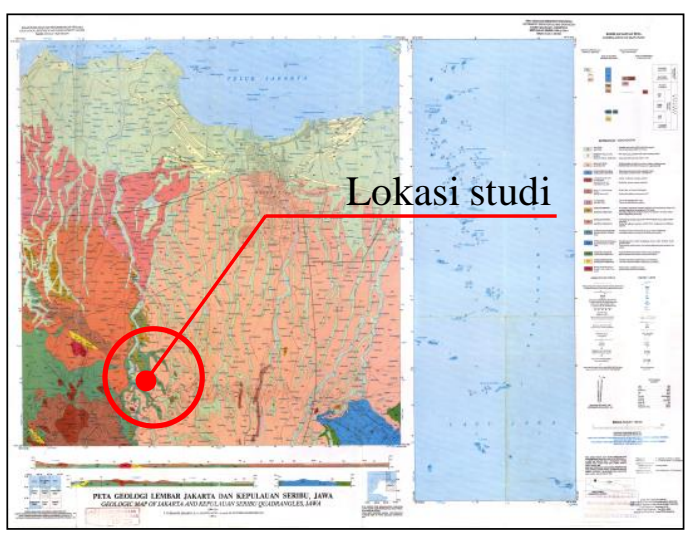

Gambar 2. Lokasi jalan Suradita-Kranggan

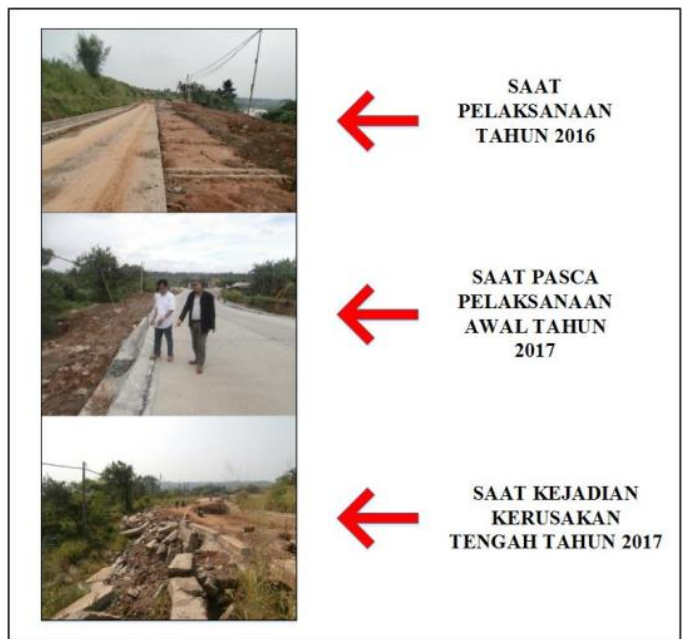

Gambar 3. Kronologis kerusakan badan jalan

\section{METODE PENELITIAN}

Bagan alir diperlihatkan dalam Gambar 4. Data tanah diperoleh dari Suku Dinas Pekerjaan Umum (SDPU) Kabupaten Tangerang. Data berupa data SPT dan Sondir (CPT). Tipikal data diperlihatkan dalam Gambar 5.

Precast Prestress Concrete Pile atau disebut juga dengan Spun Pile yaitu tiang berbahan dasar dari beton prategang yang menggunakan baja penguat dan kabel kawat sebagai gaya prategangnya (Irawan et al, 2014). 
Putera Agung MA, Dea P T. Plat Spun Pile...

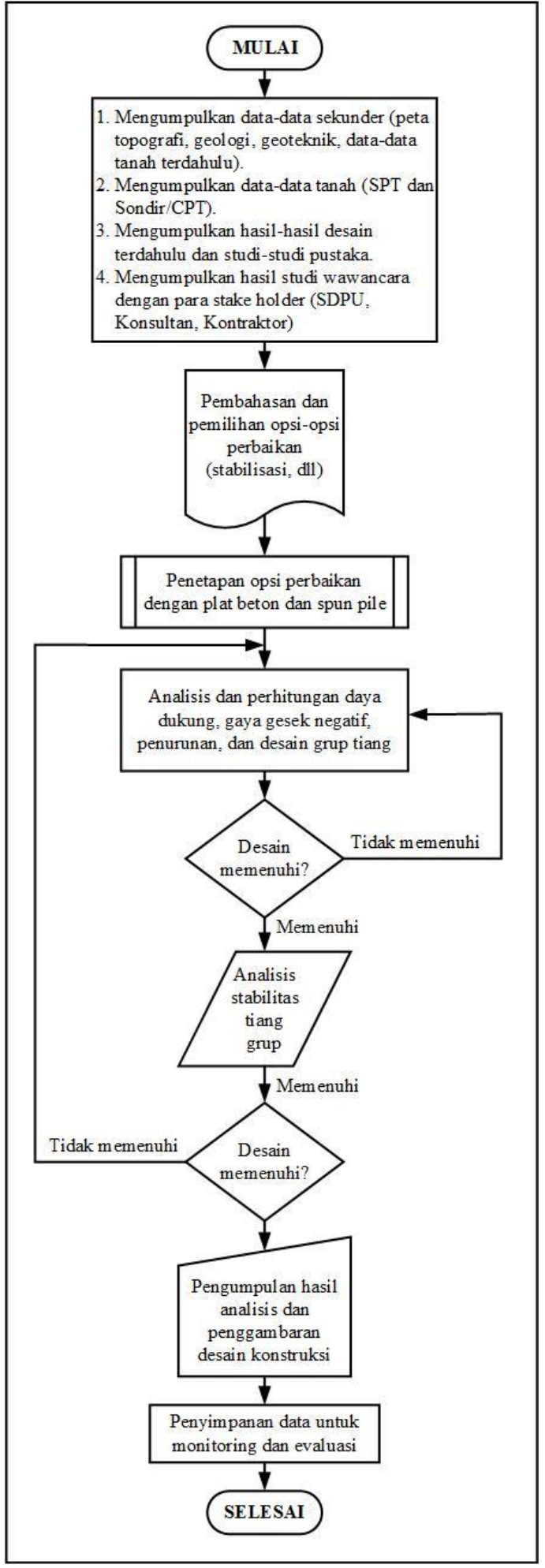

Gambar 4. Bagan alir studi desain

Sistem kombinasi plat beton dan spun pile ini sangat mirip dengan sistem CMC atau jembatan konvensional. Dengan demikian, sistem perkerasan kaku dan atau fleksibel bisa diletakkan di atas sistem plat beton-spun pile ini.
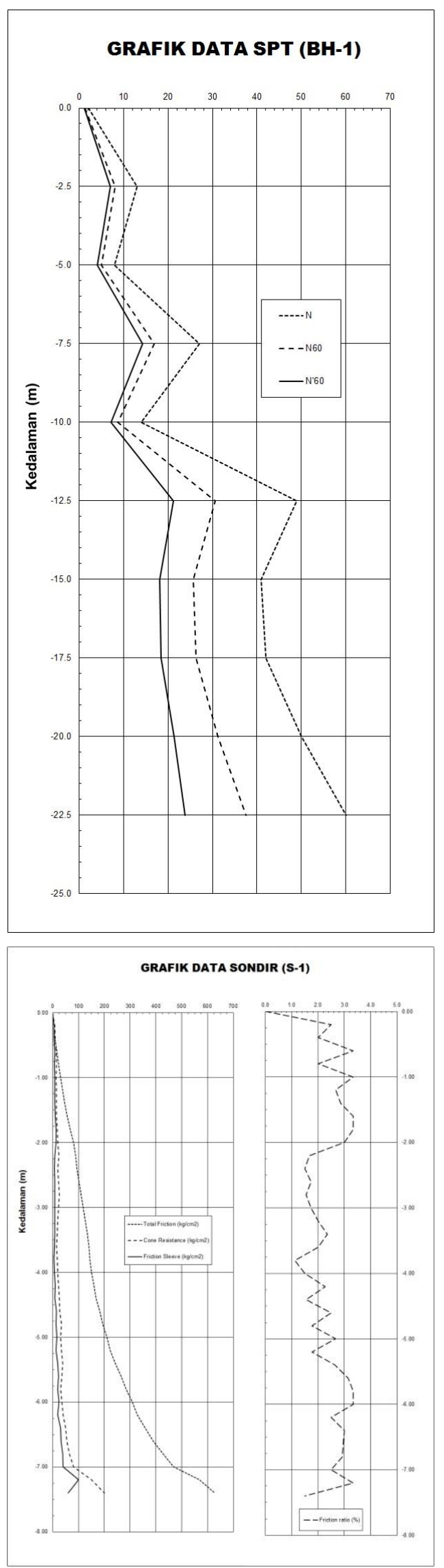

Gambar 5. Data tanah tipikal 
Perhitungan daya dukung tunggal menggunakan data SPT metode Meyerhoff (1976), data CPT metode Schmertmann (1970; 1978), dan daya dukung lateral metode Broms (1965). Penurunan dan tahanan gesek negatif, yang dianalisis ialah tiang tunggal menggunakan metode Das (1981). Pembebanan dilakukan menggunakan aplikasi perangkat lunak SAP 2000 dengan acuan peraturan pembebanan SNI 1725-2016. Hasil dari perhitungan tiang tunggal akan digunakan sebagai acuan desain tiang kelompok.

\section{HASIL dan PEMBAHASAN}

Perhitungan dilakukan menggunakan tiang dengan panjang $1400 \mathrm{~cm}$ dan diameter $50 \mathrm{~cm}$ (data lihat Lampiran-1).

\subsection{Daya dukung tiang tunggal}

Daya dukung tiang pancang dari data hasil uji SPT pada titik uji SPT BH-01 : $Q_{b}=93,63.1964,29=183,90$ ton $Q_{s}=0,52.220000=144,40$ ton $Q_{u l t}=Q_{b}+\mathrm{Q}_{s}=296,86$ ton $Q_{i j i n}=\frac{Q_{b}}{3}+\frac{Q_{s}}{5}=84,29$ ton

Daya dukung tiang pancang dari data hasil uji CPT titik uji CPT S-1:

$\mathrm{Q}_{\mathrm{p}}=200,00 \times 1964,29=392,85$ ton

$\mathrm{Q}_{s}=0,5085 \times 220000=111,87$ ton

$\mathrm{Q}_{\text {ult }}=\mathrm{Q}_{\mathrm{p}}+\mathrm{Q}_{\mathrm{s}}=504,34$ ton

$Q_{i j i n}=\frac{Q_{b}}{3}+\frac{Q_{s}}{5}=133,18$ ton

\subsection{Penurunan elastis $\left(S_{e}\right)$}

Penurunan elastis tiang tunggal $\mathrm{Se}_{(1)}$ :

$$
\begin{aligned}
\mathrm{S}_{\mathrm{e}(1)}= & \frac{(61304,60+0,67.4119669,17)}{1964,29.395240} \\
& .1400 \\
= & 49,774 \mathrm{~mm}
\end{aligned}
$$

Penurunan elastis tiang akibat beban tahanan ujung $S_{\mathrm{e}(2)}$ (Hardiyatmo, 2006):
$\mathrm{S}_{\mathrm{e}(2)}=\frac{31,21 \cdot 50}{900}\left(1-0,85^{2}\right) \cdot 0,85=11,75 \mathrm{~mm}$

Penurunan elastis tiang akibat beban sepanjang selimut tiang $\mathrm{Se}_{(3)}$ :

$$
\begin{aligned}
S_{e(3)}= & \left(\frac{4119669.17}{157,08 \cdot 1400}\right) \cdot \frac{50}{900}\left(1-0,85^{2}\right) \\
= & 31,852 \mathrm{~mm}
\end{aligned}
$$

Penurunan Elastis Total Tiang $\left(\mathrm{S}_{\mathrm{e}}\right)$ : $\mathrm{S}_{\mathrm{e}}=49,774+11,75+31,97=93,50 \mathrm{~mm}$

$$
\mathrm{S}_{e}<100 \mathrm{~mm} \quad \mathrm{OK}
$$

\subsection{Daya dukung lateral tiang}

$$
\beta=\sqrt[4]{\frac{1,99.50}{4.395240 .255324 .3}}=0,00396
$$

$\beta . L=5,547>2,5 \rightarrow$ Tiang Panjang Momen batas lentur tiang

$$
\begin{aligned}
M_{y} & =4000.12276 .786 \\
& =49107142.857 \mathrm{~kg}-\mathrm{m}
\end{aligned}
$$

Momen ultimit lateral tiang pancang :

$$
\frac{\mathrm{M}_{\mathrm{y}}}{c_{u} \cdot D^{3}}=\frac{4000 \cdot 12276 \cdot 786}{1,753 \cdot 50^{3}}=224,144
$$

Hasil yang diperoleh selanjutnya diplot pada grafik Broms (1965) pada Gambar 6 untuk kondisi kepala tiang bebas dan terjepit di bawah ini.

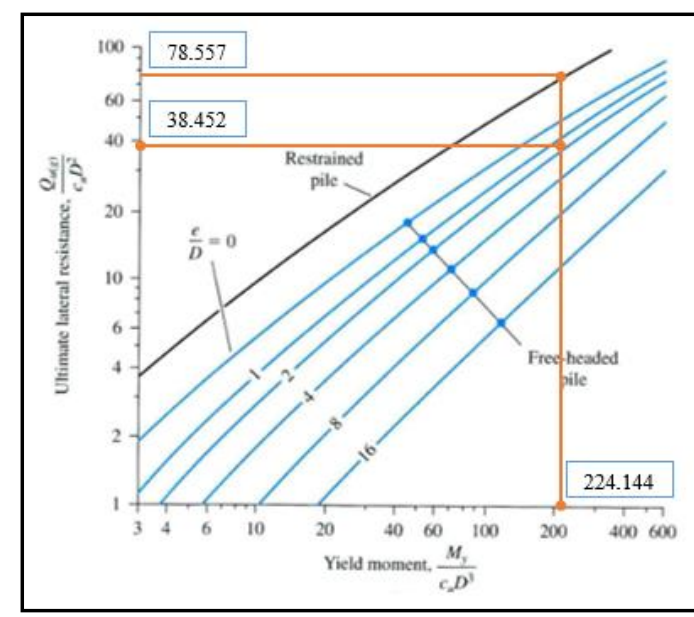

Gambar 6. Faktor tahanan lateral tiang

Didapatkan hasil plot grafik untuk tiang bebas 38,452 dan tiang jepit 78,557. Demikian nilai $\mathrm{Q}_{\mathrm{u}}$ lateral tiang ujung bebas adalah sebagai berikut: 


$$
\begin{aligned}
\frac{\mathrm{Q}_{\mathrm{u}(g)}}{c_{u} \cdot D^{2}} \rightarrow Q_{u(g)} & =38,452 \cdot 1,753 \cdot 50^{2} \\
& =168,49 \text { ton }
\end{aligned}
$$

Nilai $Q_{u}$ lateral tiang ujung jepit:

$$
\begin{aligned}
\frac{\mathrm{Q}_{\mathrm{u}(g)}}{c_{u} \cdot D^{2}} \rightarrow Q_{u(g)} & =78,557 \cdot 1,753 \cdot 50^{2} \\
& =344,22 \text { ton }
\end{aligned}
$$

Kontrol Daya Dukung Lateral Ijin Berdasarkan Persyaratan Defleksi dimana $\left(X_{z(z=0)}\right.$. K.D.L $\left./ Q_{g}\right)$.

$$
\beta(\mathrm{L})=\sqrt[4]{\frac{1,99.50}{4.395240 .255324 .3}} \cdot 1400
$$

Hasil yang diperoleh selanjutnya diplot pada grafik Broms (1965) pada Gambar 7 untuk kondisi kepala tiang bebas dan terjepit di bawah ini untuk menentukan besar faktor defleksi lateral yang terjadi.

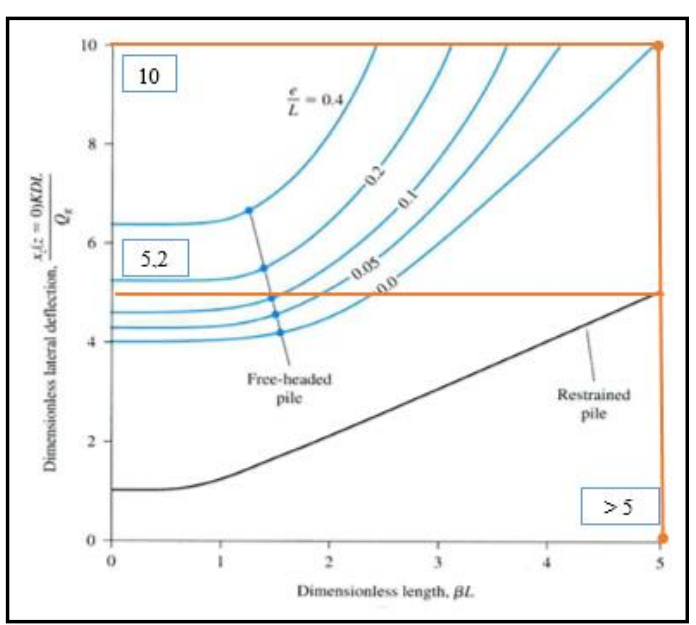

Gambar 7. Faktor defleksi lateral tiang

Dari hasil plot grafik pada Gambar 7 didapatkan faktor defleksi pada tiang ujung bebas adalah 10 dan pada tiang ujung jepit sebesar 5,2 (Das, 2011).

Nilai $Q_{\mathrm{g}}$ kondisi bebas:

$$
\begin{aligned}
Q_{g} & =\frac{1,9 \cdot 30 \cdot 1400 \cdot 1,27}{10} \\
& =17,69 \text { ton } \leq 168,49 \text { ton }(\mathrm{OK})
\end{aligned}
$$

Nilai $Q_{g}$ kondisi jepit:

$$
\begin{aligned}
Q_{g} & =\frac{1,9 \cdot 30 \cdot 1400 \cdot 1,27}{5,2} \\
& =34,02 \text { ton } \leq 344,22 \text { ton }(\mathrm{OK})
\end{aligned}
$$

\subsection{Gesek negatif}

Tahanan gesek negatif tiang tunggal untuk lapisan tanah lempung diatas lapisan tanah pasir (Das, 2009).

$$
\begin{aligned}
\mathrm{Q}_{\mathrm{n}}= & \frac{200 \cdot 0,505.0,0019.1500^{2}}{2} \\
& \cdot \tan 20,8^{\circ} \\
= & 81,882 \text { ton }<133,18 \text { ton } \quad(\mathrm{OK})
\end{aligned}
$$

\subsection{Pola susunan tiang grup}

Berdasarkan hasil analisis dengan menggunakan software SAP 2000, maka diperoleh reaksi titik sambung (joint) atau tumpuan diatas akan digunakan untuk menghitung beban yang akan ditanggung pada tiang kelompok atau grup:

$P_{\mathrm{v}}=296,36$ ton

$\mathrm{M}_{\mathrm{x}}=6,331$ ton-cm

$\mathrm{M}_{\mathrm{y}}=3026,4$ ton $-\mathrm{cm}$

$\mathrm{H}_{\mathrm{x}}=18,573$ ton

$\mathrm{H}_{\mathrm{y}}=0,0378$ ton

Diambil pola susunan segi empat.

\subsection{Jumlah tiang grup}

Jumlah tiang pancang (n)

$$
\begin{array}{ll}
\mathrm{n}_{\mathrm{p}}=\frac{\mathrm{P}}{\mathrm{P}_{\mathrm{t} \text { CPT }}}=\frac{296,36}{133,18}=2,225 & \approx 3 \text { buah } \\
\mathrm{n}_{\mathrm{p}}=\frac{\mathrm{P}}{\mathrm{P}_{\mathrm{t} \text { SPT }}}=\frac{296,36}{84,29}=3,515 & \approx 4 \text { buah }
\end{array}
$$

Rencana kelompok tiang terdiri atas 3 kolom dan 2 baris dengan jumlah tiang sebanyak 6 buah (Gambar 8).

Efisiensi tiang (Converse - Labbarre dari Uniform Building Code AASHTO), (AASHTO, 2010), yaitu:

$$
\begin{aligned}
E_{g} & =1-26,57\left[\frac{(3-1) 2+(2-1) 3}{90 \cdot 2 \cdot 3}\right] \\
& =0,66
\end{aligned}
$$




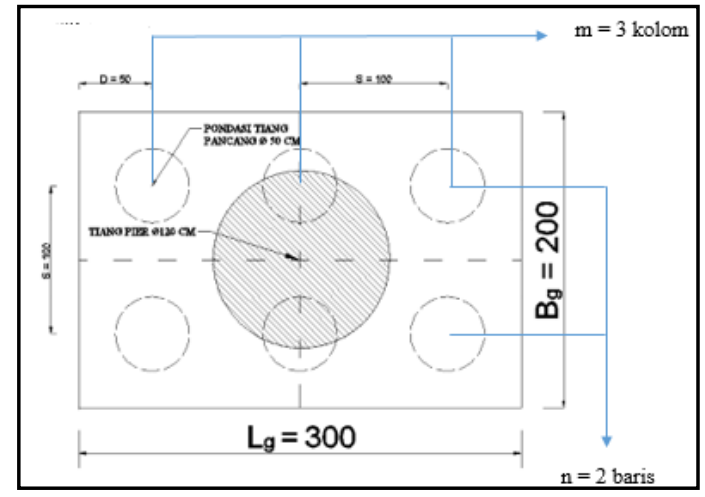

Gambar 8. Pola susunan tiang grup

\subsection{Daya dukung grup tiang}

Daya dukung kelompok tiang berdasarkan jumlah tiang dan daya dukung tiang tunggalnya:

Daya dukung hasil berdasarkan hasil uji $\mathrm{CPT}=133,18$ ton

$\mathrm{Q}_{\mathrm{g}(\mathrm{u})}=0,66.6 .133,18=331,60$ ton

Daya dukung hasil uji SPT $=84,29$ ton

$\mathrm{Q}_{\mathrm{g}(\mathrm{u})}=0,66.6 .84,29=333,79$ ton

Daya dukung kelompok tiang berdasarkan blok kelompok tiang atau (Lg.Bg.L), yaitu:

$$
\begin{aligned}
\sum \mathrm{Q}_{\mathrm{u}}= & 200.300 .1,753 \cdot 6+ \\
& \sum 2(200+300) 1,753 \cdot 1400 \\
= & 1236,59 \text { ton }
\end{aligned}
$$

\subsection{Kontrol stabilitas aksial tekan}

$$
\begin{aligned}
\mathrm{P}_{\text {maks }}= & \frac{296,36}{6} \pm \frac{3026,4.50}{3.5000} \\
& \pm \frac{6,331.50}{2.5000}=77,22 \text { ton }
\end{aligned}
$$

Daya dukung tiang tunggal hasil uji CPT: 133,18 ton $>77,22$ ton (OK) Daya dukung tiang tunggal hasil uji SPT: 84,29 ton $>77,22$ ton (OK) Demikian, kondisi spun pile dalam keadaan mampu menerima beban kerja.

\section{KESIMPULAN}

Berdasarkan hasil analisis daya dukung tiang, penurunan dan sebagainya pada spun pile pada Jalan Lintas Selatan STA
0+420, Suradita - Kranggan dapat ditarik kesimpulan sebagai berikut :

a. Berdasarkan hasil analisis nilai daya dukung tiang tunggal dengan panjang tiang $1400 \mathrm{~cm}$ dan diameter $50 \mathrm{~cm}$ berdasarkan data hasil uji SPT didapatkan daya dukung sebesar 298,06 ton dan daya dukung ijin tiang 84,29 ton. Daya dukung tiang berdasarkan hasil uji CPT didapatkan sebesar 504,34 ton dan daya dukung ijin tiang 133,18 ton. Daya dukung lateral $\mathrm{Q}_{\mathrm{u}}$ tiang sebesar 168,49 ton untuk kepala tiang bebas, dan 344,22 ton untuk kepala tiang jepit. Daya dukung lateral ijin $\mathrm{Q}_{\mathrm{g}}$ adalah 17,69 ton untuk kepala tiang bebas, dan 34,02 ton untuk kepala tiang jepit. Beban aksial maksimal yang diterima tiang sebesar 77,22 ton, maka tiang dengan diameter 50 dan panjang tiang $1400 \mathrm{~cm}$ dapat mampu menerima beban aksial yang terjadi.

b. Berdasarkan hasil analisis penurunan menggunakan metode Das (1985) didapatkan penurunan elastis tiang $\left(\mathrm{S}_{\mathrm{e}(1)}\right)$ sebesar 49,774 mm, penurunan akibat beban tahanan ujung $\left(\mathrm{Se}_{(2)}\right)$ sebesar $11,75 \mathrm{~mm}$, dan penurunan elastis akibat beban yang didistribusi sepanjang selimut tiang sebesar $31,97 \mathrm{~mm}$. Penurunan total tiang sebesar $\left(\mathrm{S}_{\mathrm{e}}\right)$ sebesar 93,50 $\mathrm{mm}$. Penurunan elastis tiang total termasuk aman (Skempton \& Bjerrum (1957) dan Skempton \& MacDonald (1956) (maks. 100 mm).

c. Berdasarkan hasil analisis didapatkan tahanan gesek negatif adalah sebesar 81,882 ton (Meyerhoff, 1963).

d. Berdasarkan perhitungan daya dukung tiang tunggal dan lateral, penurunan elastis, dan daya gesek negatif tiang tunggal didapatkan yang memenuhi ijin adalah dimensi tiang pancang dengan diameter 50 $\mathrm{cm}$ dan panjang tiang $14 \mathrm{~m}$.

e. Rencana kelompok tiang dengan 3 kolom dan 2 baris dan berjumlah tiang 6 buah diperhitungkan aman. 
f. Berdasarkan hasil analisa daya dukung kelompok tiang didapatkan daya dukung tiang berdasarkan jumlah tiang dan daya dukung tiang tunggalnya sebesar 331,60 ton (daya dukung tiang tunggal berasal dari hasil uji CPT) dan 333,79 ton (daya dukung tiang tunggal berasal dari hasil uji SPT) dan daya dukung blok sebesar 1236,59 ton. Gambar desain pada bagian Lampiran-2.

\section{UCAPAN TERIMA KASIH}

Penulis mengucapkan terima kasih atas dukungan data-data dari Suku Dinas Pekerjaan Umum, Pemerintah Daerah Kabupaten Tangerang. Dan tidak lupa kepada Lembaga IBIKK Politeknik Negeri Jakarta atas dukungan untuk melaksanakan studi desain ini.

\section{DAFTAR PUSTAKA}

[1] AASHTO LRFD. 2010. Bridge Design Specifications.

[2] Broms, B. 1965. The Lateral Resistance of Piles in Cohesive Soils. J. Soil Mech. Found. Div., ASCE, Vol. 90, pp. 27-63

[3] Clisby, M.B., Scholtes, R.M., Corey, M.W., Cole, H.A., Teng, P., and Webb, J.D. 1978. An Evaluation of Pile Bearing Capacities, Volume I, Final Report, Mississippi State Highway Department.

[4] Das, Braja M. 2009. Principle of Foundation Engineering. Boston : Publishing company.

[5] Das, B.M. 2011. Principles of Foundation Engineering. Seventh Edition, 200 First Stamford Place, Suite 400 Stamford, CT 06902, USA.

[6] Hardiyatmo, H.C. 2010. Analisis dan Perancangan Fondasi II. Yogyakarta : Gadjah Mada University Press.
[7] Irawan, Candra; dkk. 2014. A Review of Prestressed Concrete Pile with Circular Hollow Section (Spun Pile). Surabaya : UTM Press.

[8] Meyerhoff, G.G. 1963. Some Recent Research on the Bearing Capacity of Foundations. Canadian Geot. Jnl., Vol. 1, No. 1, pp. 16-26.

[9] Meyerhof, G.G. 1976. Bearing capacity and settlement of pile foundations. The Eleventh Terzaghi Lecture, November 5, 1975. American Society of Civil Engineers, ASCE, Journal of Geotechnical Engineering, Vol. 102, GT3, pp. 195 - 228.

[10] SNI-1725-2016. 2016.

Pembebanan Jembatan. Jakarta : Badan Standardisasi Nasional.

[11] Schmertmann, J.H., (1970), Static Cone to Compute Static Settlement over Sand. Journal. Soil Mech. \& Found. Div., ASCE, Vol. 96, No. SM3, pp. 1011-1043.

[12] Schmertmann, J.H. 1978. Guidelines for Cone Penetration Test, Performance and Design. U.S. Department of Transportation, Report No. FHWA-TS-78-209, Washington, D.C., p. 145.

[13] Skempton, A.W. and Bjerrum, L. 1957, A Contribution to the Settlement Analysis of Foundations on Clay, Geotechnique, Vol. 7, p. 168.

[14] Skempton, A.W., and MacDonald, D.H. 1956. The Allowable Settlement of Buildings. Proc. I.C.E. London, Part 3, pp. 727-784.

[15] Turkandi et al. 1992. Peta Geologi Lembar Jakarta dan Kepulauan Seribu, Jawa skala 1:100.000. Bandung. Dit. P3G, Dit. Geologi dan Sumberdaya Mineral. 
Putera Agung MA, Dea P T. Plat Spun Pile...

Lampiran-1 Data SPT BH-1 dan CPT-S-1 (dalam angka)

\begin{tabular}{|c|c|c|c|c|c|c|c|c|c|c|}
\hline \multicolumn{11}{|c|}{ STANDARD PENETRATION TEST } \\
\hline $\begin{array}{l}\text { Project } \\
\text { Test No. } \\
\text { Site name } \\
\text { Location } \\
\end{array}$ & $\begin{array}{l}\text { : Jalan } \\
: \text { BH-1 } \\
: \text { Jalan K } \\
: \text { Jalan R } \\
\end{array}$ & $\begin{array}{l}\text { anggan } \\
\text { ya Krangg }\end{array}$ & uradita & & & & & $\begin{array}{l}\text { Date } \\
\text { Tested by } \\
\text { Weather } \\
\text { GWL }\end{array}$ & $\begin{array}{l}\text { Mei 2017 } \\
: \text { Asep } \\
: \text { Fine } \\
-\cdots-m \\
\end{array}$ & \\
\hline \multicolumn{11}{|c|}{$\begin{array}{l}\text { PERHITUNGAN DATA SPT } \\
\end{array}$} \\
\hline \multirow[t]{2}{*}{ Depth } & \multirow[t]{2}{*}{$\mathrm{N}$} & \multicolumn{4}{|c|}{ Parameter-parameter koreksi peralatan dan lokasi } & \multirow{2}{*}{$\mathrm{N}_{60}$} & \multirow{2}{*}{$\begin{array}{c}\text { Perbandingan } \\
\left(\sigma_{y} / \sigma_{f}\right)\end{array}$} & \multirow{2}{*}{$\begin{array}{c}\text { Koreksi } \\
\left(C_{N}\right)\end{array}$} & \multirow{2}{*}{$\mathrm{N}_{60}$} & \multirow{2}{*}{ Lapisan tanah } \\
\hline & & $E_{m}$ & $c_{\mathrm{B}}$ & $c_{s}$ & $C_{R}$ & & & & & \\
\hline (A) & (B) & (c) & (D) & (E) & (F) & (G) & $(\mathrm{H})$ & (I) & (J) & (K) \\
\hline 0.00 & 2 & 0.5 & 1.0 & 1.0 & 0.75 & 1.25 & 1.1 & 0.95 & 1.19 & Urugan pasir. lanau \\
\hline-2.50 & 13 & 0.5 & 1.0 & 1.0 & 0.75 & 8.13 & 1.32 & 0.86 & 7.00 & Lempung. kenyal. \\
\hline-5.00 & 8 & 0.5 & 1.0 & 1.0 & 0.75 & 5.00 & 1.45 & 0.62 & 4.08 & \\
\hline-7.50 & 27 & 0.5 & 1.0 & 1.0 & 0.75 & 16.88 & 1.57 & 0.84 & 14.18 & Pasir kasar, lempung, \\
\hline-10.00 & 14 & 0.5 & 1.0 & 1.0 & 0.75 & 8.75 & 1.65 & 0.82 & 7.19 & abu-abu tua \\
\hline-12.50 & 49 & 0.5 & 1.0 & 1.0 & 0.75 & 30.63 & 1.75 & 0.69 & 21.25 & Batu pasir abu-abu tua \\
\hline-15.00 & 41 & 0.5 & 1.0 & 1.0 & 0.75 & 25.63 & 1.84 & 0.70 & 18.05 & \\
\hline-17.50 & 42 & 0.5 & 1.0 & 1.0 & 0.75 & 26.25 & 1.86 & 0.70 & 18.36 & Lempung kenyal, coklat \\
\hline-20.00 & 50 & 0.5 & 1.0 & 1.0 & 0.75 & 31.25 & 1.93 & 0.68 & 21.33 & \\
\hline-22.50 & 60 & 0.5 & 1.0 & 1.0 & 0.75 & 37.50 & 1.98 & 0.63 & 23.79 & Eatuan pasii keras, abu \\
\hline-25.00 & & & & & & & & & & \\
\hline
\end{tabular}

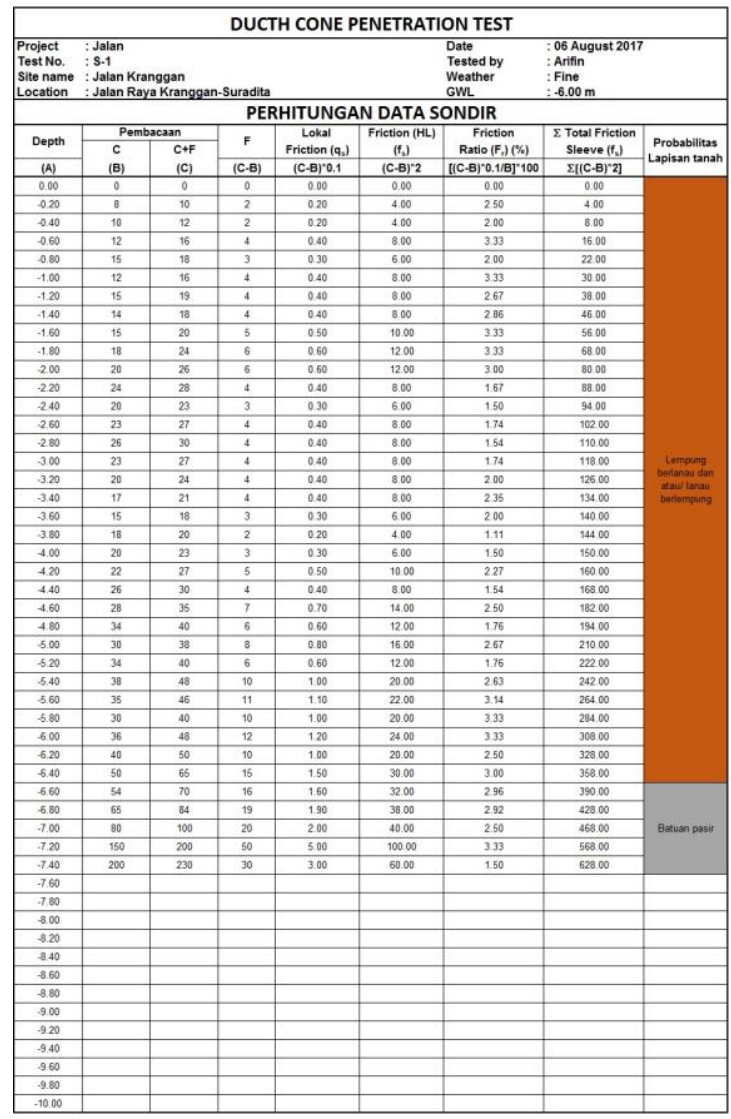

Lampiran-2 Gambar skematis desain konstruksi

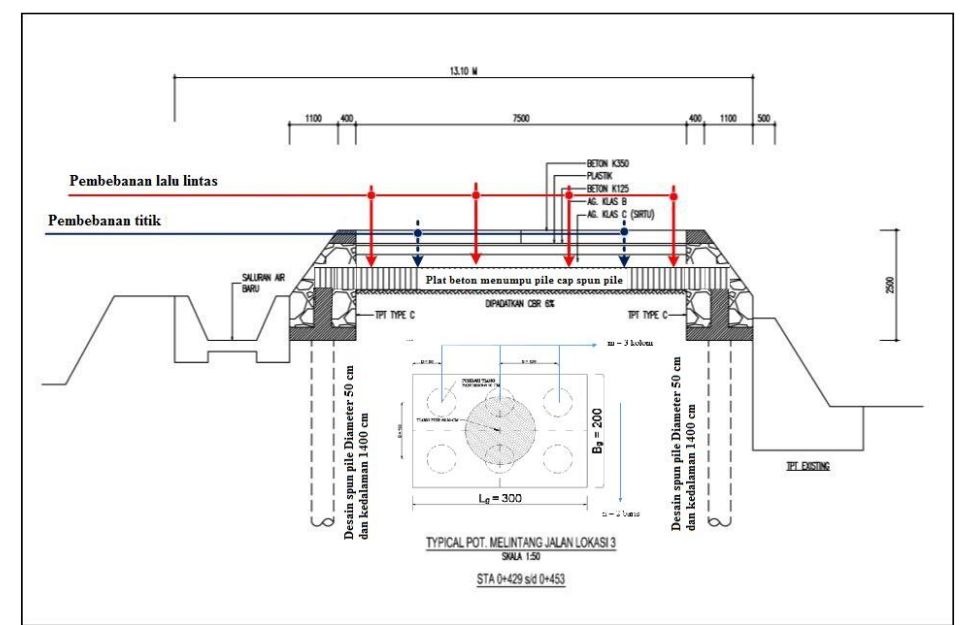

